\title{
THE FOURTH INDUSTRIAL REVOLUTION: EXPLORING THE DETERMINANTS OF INTERNET ACCESS IN EMERGING ECONOMIES
}

\author{
David MHLANGA* \\ The University of Johannesburg, Republic of South Africa \\ John BENEKE \\ The Vaal University of Technology, Republic of South Africa
}

\begin{abstract}
With the rapid developments and changes in technology in the Fourth Industrial Revolution being witnessed everywhere, this study aimed to investigate the factors that influence access to the internet by households in emerging economies with a direct focus on South Africa one of the countries in Sub-Saharan Africa. Access to broadband facilities by individuals, households and consumers is one of the critical components of the economic growth and prosperity of a country. It is generally believed that the access to broadband technologies by a community or nation helps to increase productivity which assists a lot in fueling economic growth which will have an impact on the levels of poverty. Using the logistic regression, the study found out that race, access to telephone landline, access to a cellular cellphone, access to electricity, owning a house, gender, age of the household head, net household income per month, and household expenditure were the significant variables in influencing the demand for internet access by households in emerging economies. The factors that were more important in the influence on access to the internet were the availability of electricity and access to a cellphone. Therefore, the study concludes that to improve the quality of life of the people, it is imperative that the governments across the world, do invest more in improving access to quality internet, but one of the prerequisites is that households should have a stable electricity supply and they have access to cellphones.
\end{abstract}

Keywords: access, determinants, the fourth industrial revolution, internet access, South Africa

JEL Classification: L8, M15.

\footnotetext{
* Corresponding author. Address: The University of Johannesburg, Department of accountancy, PO Box 524, Auckland Park, 2006, South Africa, dmhlanga67@gmail.com, Orcid ID: orcid.org/0000-0002-8512-2124
} 


\section{Introduction}

The Fourth Industrial Revolution (4IR) is becoming more and more real to humanity. One of the factors that cause people to be anxious about the developments is the fact that 4IR is associated with the potential of raising global incomes which will help in the improvement of the quality of life of the people (Mhlanga \& Moloi, 2020). However, it is also believed that the 4IR will come with disruptions in almost all the sectors of the economy (Schwab, 2017). There is a general belief that $4 \mathrm{IR}$ will be greatly associated with greater inequality, severe job losses, climate change risks such as heatwave and the rising of oceans. The 4IR is characterized by the fusion of technologies that is blurring the lines between the physical, digital, and biological worlds (Xu et al., 2018)

Scholars believe that the 4IR is building its strength on the capabilities of the third industrial revolution and it is characterized by various technologies such as mobile supercomputing, intelligent robots, self-driving cars among other notable technologies (Schwab, 2017). Schwab (2017) went on to argue that with the potential of the 4IR the world has a lot of potentials to connect billions of people to digital networks which will improve the efficiency of organizations. Schwab (2017) also asserted that the ability to connect the world can also assist in the management of assets in ways that can help in regenerating the natural environment which can go on to undo the damage of the past revolutions. Without proper, affordable, reliable, and efficient internet connectivity it will be very difficult for a community or a government to be able to realize the benefits associated with the 4IR let alone to be able to hedge against the potential problems associated with this revolution (Lee et al., 2018). This was supported by Schwab (2017) who argued that with the rapid changes in technology governments may fail to adapt, employ, and regulate new technologies to be able to effectively capture their benefits.

All this points to the fact that internet connectivity, the issue of the digital divide by some of the central technology that should be available to the people (Lee et al., 2018; Schwab, 2017).

The changes over the years in internet access technology, from dial-up to broadband, have caused a considerable debate on the digital divide (Flamm \& Chaudhuri, 2007; Lembani et al., 2020). Currently, much focus is on ubiquitous broadband and high speed city-wide wireless access (Flamm \& Chaudhuri, 2007; Lembani et al., 2020). Access to broadband facilities by individuals, households and consumers is one of the critical components of the economic growth and prosperity of a country. It is generally believed that access to broadband technologies by a community or nation helps to increase productivity which assists a lot in fueling economic growth which will have an impact on the levels of poverty (Grosso, 2006; Lembani et al., 2020). The emergence of bandwidth-intensive technologies such as video communication, 5th generation network and various applications has reinforced the importance of access to broadband and its importance in the development of a community, region and even continent (Drake et al., 2019; Grosso, 2006). Kekana (2013) also argued that broadband access can come with many benefits on productivity, education, health, internet inclusion economic growth and development. The argument by Kekana (2013) was that to achieve substantial progress in health care, education, business, and government access to speed and stable internet are some of the prerequisites. This was also supported by Ang et al. (2020) who argued that internet use becoming 
a necessity, yet older adults may not use the internet due to health and non-health reasons like lack of digital literacy or visual impairment and sometimes movement difficulties.

The World Bank (2020a) also supports the view that broadband access has a strong economic value for the government and the citizens. It is argued that internet access is a necessity for economic and human development in both developed and developing countries (The World Bank, 2020a). The World Bank (2020a) went on to argue that internet access is a powerful tool for delivering essential services like education and healthcare, increasing the opportunities for women's empowerment and environment sustainability, and contributing to enhanced government transparency and accountability. There is also an argument that internet access helps to foster the social development of communities. Various other studies documented the factors that influence households' access to broadband. Flamm \& Chaudhuri (2007) analyzed the impact of the various socio-economic factors on the decision by households to subscribe to dial-up internet access.

The authors discovered that the price of broadband has an impact on access to broadband. Another study by Lera-López et al., (2009) assessed the impact of socioeconomic and demographic factors in influencing internet use and the frequency of use by individuals in Spain. Through employing binomial and ordered logit models the authors discovered that internet use was influenced by the level of education, age, occupation, employment in the service sector, the nationality of the individual, location that is where an induvial resides in urban areas and regional gross domestic product. The study also discovered that frequency is positively influenced by the level of education, gender, and the size of the population Lera-López et al. (2009).

Another study was done by Al-Hammadany \& Heshmati (2011) discovered that the internet is one of the advanced technologies that are critical in facilitating communication and trade. In the same study Al-Hammadany \& Heshmati (2011) conceded that from its inception in the 1960s, the internet has been so influential in the creation of opportunities and favorable conditions for growth in developing and developed nations. Al-Hammadany \& Heshmati (2011) also highlighted that factors such as "lack of adequate resources, insufficient incentives and encouragement from the government, and social inhibitions" were the factors that were affecting the effective adoption of the internet in Iraq. Motivated by these findings the study intends to investigate the factors that influence internet demand by households in Sub-Saharan Africa with a specific focus on South Africa.

\section{The Fourth Industrial Revolution}

The world went through major technological advances termed the First Industrial Revolution, the Second Industrial Revolution, Third Industrial Revolution, and the Fourth Industrial Revolution (Li et al., 2017). The first industrial Revolution is argued to be started in Great Britain with the introduction of hydraulic and stream engine (Li et al., 2017; Schwab, 2017). The Second Industrial Revolution attained the separation of components and assembly of products based on specialization and division of labour (Lee et al., 2018; Mhlanga, 2020b). The Third Industrial Revolution is associated with a wide application of the electronic and information technology automation of manufacturing processes (Li et al., 2017). Currently, the world is going 
through another wave popularly known as the Fourth Industrial Revolution characterized by the application of cyber-physical systems in the manufacturing environment (Mhlanga, 2020; Schwab, 2017).

The Fourth Industrial Revolution is creating hyper-connectivity based on monitoring, analyzing and digitizing with an impact on how human and machine, human and human, machine and machine (Park, 2018). Hyperconnectivity is making communication to be universal, global and to be instant communication (Park, 2018). The Fourth Industrial Revolution is also characterized by wider application of artificial intelligence (Al) which is enabling data massive data processing including issues related to language processing and images which computers are not able to fathom (Park, 2018). Figure 1 is showing the fourth industrial revolutions.

Figure 1: Industrial Revolutions

\begin{tabular}{|cc|c|c|}
\hline $\begin{array}{c}\text { The First } \\
\text { Industrial } \\
\text { Revolution- } \\
\text { through the } \\
\text { introduction of } \\
\text { mechanical } \\
\text { production } \\
\text { facilities with the } \\
\text { help of water and } \\
\text { steam power. } \\
\begin{array}{c}\text { First Mechanical } \\
\text { loom } 1784\end{array}\end{array}$ & $\begin{array}{c}\text { Second Industrial } \\
\text { through the } \\
\text { division of labour } \\
\text { and mass } \\
\text { production with the } \\
\text { help of electrical } \\
\text { energy. First } \\
\text { assembly line } \\
1870\end{array}$ & $\begin{array}{c}\text { Third Industrial } \\
\text { Revolution- } \\
\text { through the use } \\
\text { of electronic and } \\
\text { IT systems that } \\
\text { further automate } \\
\text { production. 1969 }\end{array}$ & $\begin{array}{c}\text { The Fourth } \\
\text { Industrial } \\
\text { Revolution- } \\
\text { through the } \\
\text { use of cyber- } \\
\text { physical } \\
\text { systems. } \\
\text { Today }\end{array}$ \\
\hline
\end{tabular}

Source Author's Analysis

The figure above shows the four industrial revolutions, the First Industrial Revolution, the Second Industrial Revolution, the Third Industrial Revolution and Mhlanga (2020a) stated that the impact of the Fourth Industrial Revolution on humanity will not only result in job losses but will also have an impact on how public and private goods are delivered. Chung \& Kim, (2016) also believe that the Fourth Industrial Revolution is not only changing the "what" and "how" we do things, but also "who" we are.

\section{A Brief Background of Internet Access}

According to Statista (2020) as of July 2020, approximately 4.57 billion people were active internet users, which is 59 per cent of the global population. Countries such as the United States of America, China and India were ahead of many countries in terms of internet use (Statista, 2020). Globally online penetration was 59 per cent with Northern Europe being the first with a 95 per cent internet penetration rate among the population (Statista, 2020). United Arab Emirates (UAE), Denmark and South Korea were the nations with the highest internet penetration while North Korea was the country with the lowest internet penetration with virtually 
no online usage penetration (Statista, 2020). For the period ending 2018, Asia was the region with the largest number of online users which were over 2 billion with Europe being the second with 705 million internet users (Seymour \& Naidoo, 2020).

In developing nations, only 35 per cent of the population has access to the internet versus an average of 80 per cent in developed nations. Broadband is also becoming the basis for smart infrastructure for example intelligent transport systems and smart electric grids. These smart technologies are facilitated by new wireless technologies (The World Bank, 2020a). It is believed that internet access can help in the creation of jobs. The World Bank (2020a) stated that raising internet penetration in developing countries can transform the economies in a great way. For instance, The World Bank (2020a) indicated that if the internet penetration increases to $75 \%$ of the population in all developing countries from the current $35 \%$ can help to add approximately US\$2 trillion to the collective gross domestic product and subsequently create 140 million jobs around the world.

\subsection{Internet Access in South Africa}

Internet access in South Africa rose from 2.4 million which was 5.35 per cent in 2000 to approximately 5 million which was 8.43 per cent in 2008 . The numbers further increased to 12.3 million which was 29.3 per cent in 2012 and 2016 the number of internet users rose to 29.3 million, this was 54 per cent of the population in South Africa (Stats SA, 2018). South Africa's internet penetration was the highest for the African continent which was 19.9 per cent. The total number of wireless broadband users in South Africa was more than that of fixed broadband users in 2007 and in 2012, the number of fixed broadband users was approximately 12.7 million while fixed-line broadband users were 1.1 million. Figure 2 shows a summary of internet users in South Africa in 2018 per province in South Africa.

Figure 2: Summary of Internet broadband users in South Africa

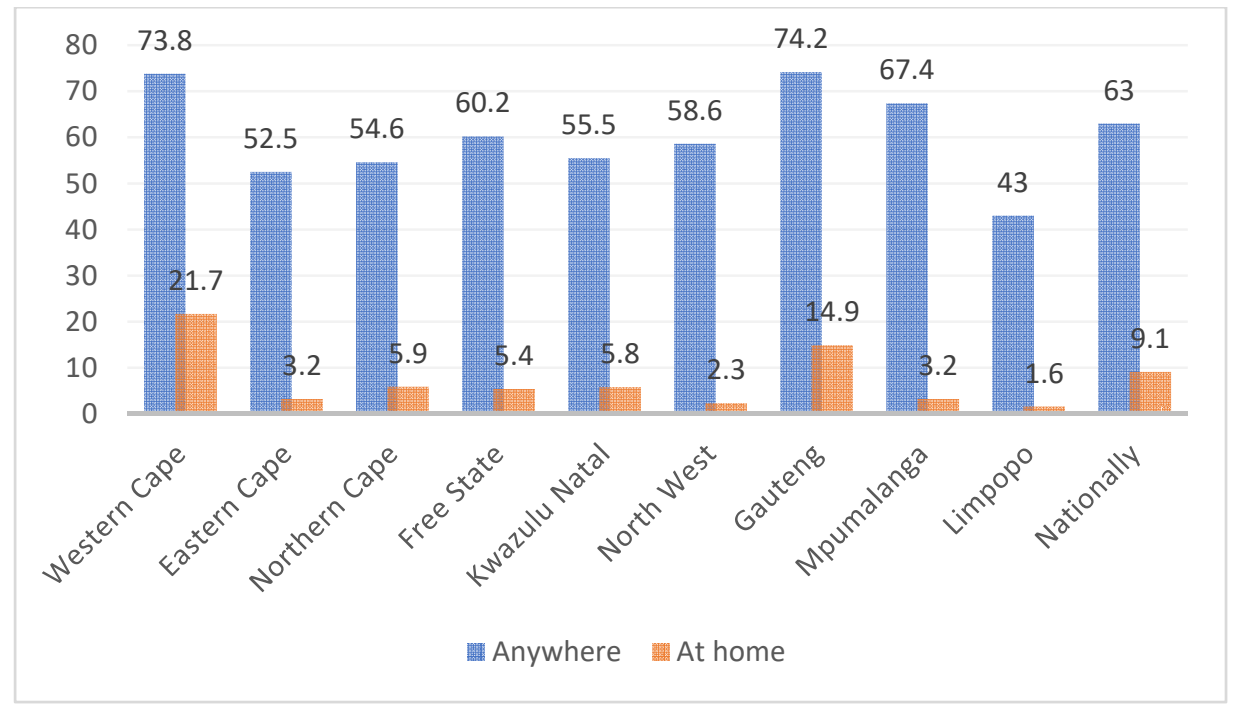

Source: Author's Analysis Stats SA (2019) data 
Figure 2 indicates that in South Africa, 63 per cent of households in South Africa had at least one member with access to or used the internet at home, internet cafes, place of work or place of study. The province with the highest use of the internet was Gauteng with 74.2 per cent followed by Western Cape with 73.8 per cent. Mpumalanga Province was the third province concerning internet use, with 67.4 per cent while Limpopo province was the lowest province concerning internet usage with 43 per cent. The table also showed that in South Africa Internet access at home was marginally about 9.4 per cent. The province with the highest internet access at home was Western Cape with 21.7 per cent followed by Gauteng with 14.9 per cent and the lowest was Limpopo with 1.6 per cent and North-West with 3 per cent (Stats SA, 2019). Figure 3 is showing individuals using the internet percentage of the population in South Africa.

Figure 3: Individuals Using the Internet (\% of Population) in South Africa from 1996-2019

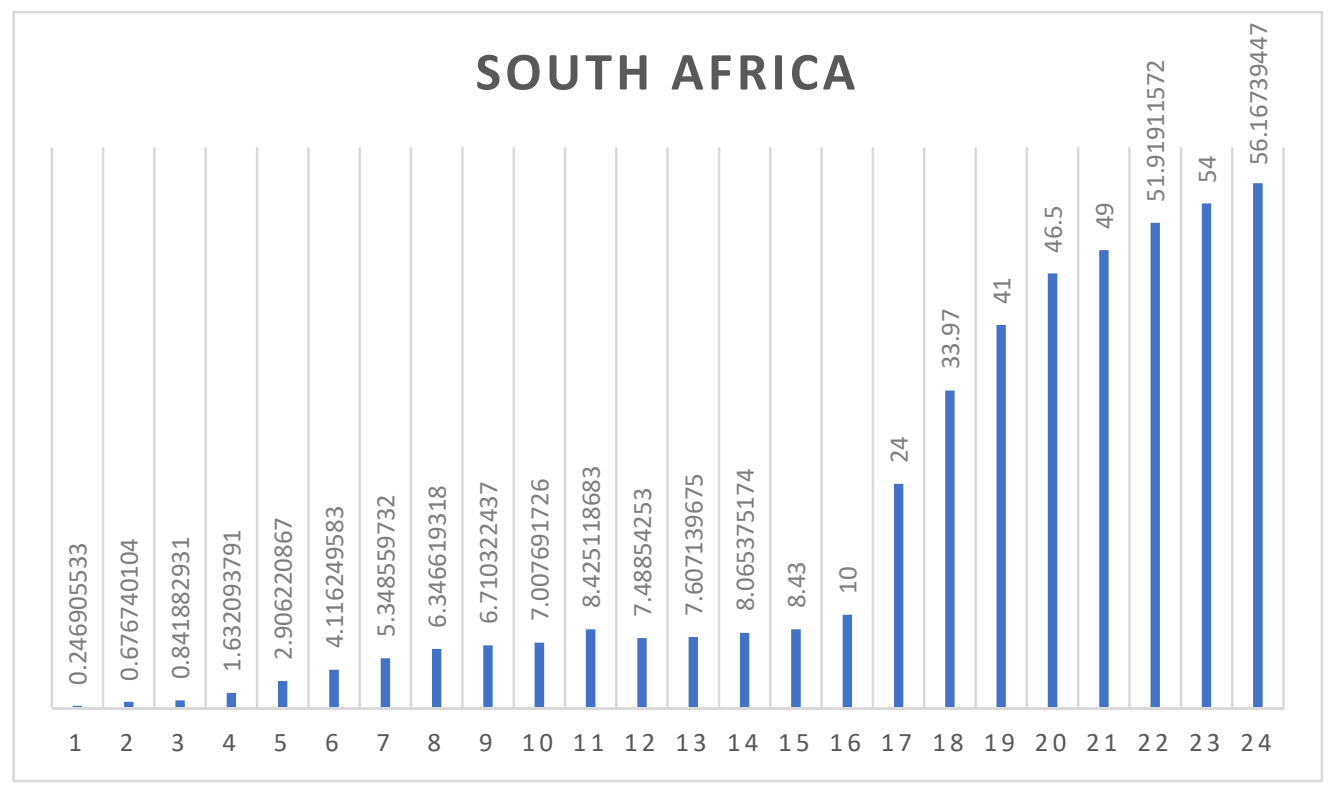

Source: The World Bank (2020b)

Figure 3 shows the individuals who are using the internet as a percentage of the population from 1996 to 2019. The information from the World Bank (2020b) was not different from the information given by Stats SA (2018). The information from the World Bank shows that Internet use in South Africa has been increasing over the years. In 2019, internet use as a percentage of the population was at $56 \%$. Figure 4 is comparing internet use in South Africa as a percentage of the population with other African countries, which are Zimbabwe, Zambia, Tanzania, and Uganda. 
Figure 4: Individuals Using the Internet \% of Population in selected African countries from 1996-2019

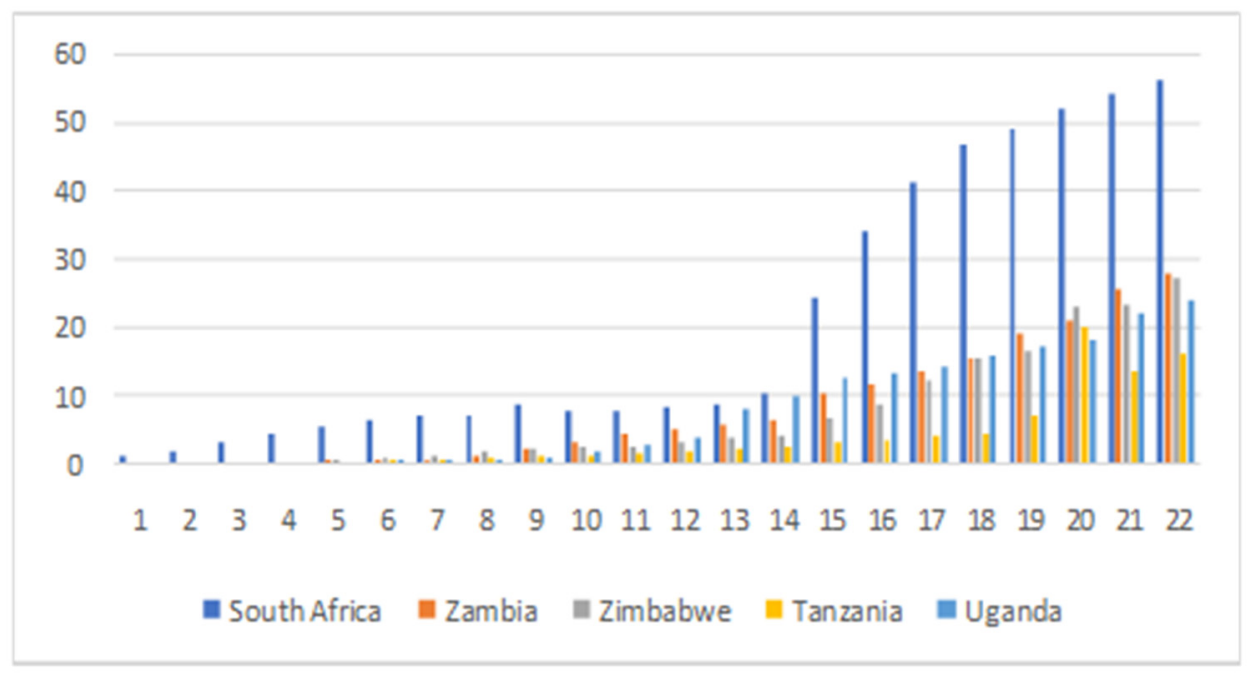

Source: Author's Analysis the World Bank (2020b)

Figure 4 shows that South Africa is at the top of the use of the internet as a percentage of the population compared to other African countries. From 1996 to 1999, no country was using the internet from the selected nations, Zimbabwe, Zambia, Tanzania, and Uganda. Internet use has been increasing in South Africa since 1996. Among the selected nations, Zambia was the next country with more people using the internet followed by Zimbabwe, Uganda, and Tanzania.

\section{Literature Review}

\subsection{Brief Background and History of the Internet}

The internet is generally defined as a global network of computers that operate in the same way as the postal system, but only at sub-second speeds (Chaudhuri et al., 2005; Trudel, 2019). The BBC-Web Wise (2012) went on to state that the internet works in the same way as the postal system as it permits people to send envelopes with messages and packets of digital data. For the internet to work, a common language is used called the transmission control protocol/internet protocol (TCP/IP). In this way, the IP address helps people to be connected to the internet. The origins of the internet are credited to the ARPnet that was created by the US defense department's advanced research project agency in the 1960s (BBCWebWise, 2012). Many different networks were then created by private commercial companies, in different countries. The only problem was that these networks could not connect. The TCP/IP was developed by Vint Cerf and Bob Kahn in 1974 and it came forth with a protocol for packet network interconnection. As a result, the internet became a network of networks although the IP dominated (BBC-WebWise, 2012). 


\subsection{Empirical Literature Review}

Empirical research on the determinants of internet access is available, for example, Flamm \& Chaudhuri (2007, 2011), Grosso (2006), Nishijima et al. (2017) among others. Chaudhuri et al. (2005) analyzed the impact of various socioeconomic on the decision of households in America on the decision to pay for basic internet access using a discrete choice framework. The study discovered that the level of education and income were strong variables that influenced the households' decision to pay for basic internet access. The study also discovered that the decision to pay for internet services was moderately sensitive to the price which motivated the authors to believe that access subsidies for basic access can help deal with the problem of the digital divide. Also, Chaudhuri et al. (2005) also extended the analysis of the impacts of socio-economic factors on a household's decision to subscribe to dial-up internet access. A cumulative utility ordered logit model was used in the analysis since demand cannot be expressed directly. It was observed that the decision to purchase was influenced by its own price elasticity broadband demand and the cross-price sensitivity of broadband concerning dialup price.

Grosso (2006) investigated the factors that influence broadband penetration in the OECD nations. Using the generalized least squares multiple regression analysis, the study discovered that competition among the various network providers increases broadband penetration. Flamm \& Chaudhuri (2007) also extended analysis of the impact of socioeconomic factors on the decision made by households to subscribe to broadband, the study also discovered that own-price elasticity of broadband demand and cross-price elasticity of demand were the variables that were statistically significant in influencing the decision by households to subscribe to broadband. Al-Hammadany \& Heshmati (2011) also discovered that the internet is one of the emerging technologies which helped create opportunities and conditions for progress. In explaining the determinants of internet use in Iraq, the results revealed that lack of adequate resources, insufficient incentives, and motivation from the government as well as social inhibitions was among the determinants of internet access by households.

Jakopin \& Klein (2018) also investigated the drivers of broadband take-up that helps to outline and evaluate the diffusion situation of a country. The study was mainly focused on worldwide broadband access, the results indicated that broadband internet take-up is important for economic growth and prosperity. Nishijima et al. (2017) also discovered that the widespread growth of information and communication technology made it possible for people to be able to participate in the social-political and economic dimensions of their daily lives. Using various inequality indexes, the study discovered that the digital divide among the people in Brazil has been decreasing over time. The study also discovered that lack of education was one of the main determinants of the digital divide in Brazil, especially among elderly people.

\section{Research methodology}

This study used the data from Stas SA (2018), General Household data (GHS). Relevant variables were extracted from the data with a total sample of 20908 distributed across all the provinces in South Africa (Stats SA, 2018). The GHS was 
introduced in 2002 to track the progress of development in South Africa. The GHS report of 2018 is showing how far South Africa progressed over the past 17 years. The target population of the survey consists of all private households in all nine provinces of South Africa and residents in workers' hostels. Collective living quarters such as old age homes student hostels, hospitals, prisons, and military barracks were not part of the survey. The survey is representative of non-institutionalised and non-military persons or households in South Africa.

\subsection{Dependent Variable}

The dependent variable was drawn from a question which was asking households to state whether the members of the household use internet services at home. The dependent variable data was recorded to appear in a binary form wherein circumstances where the household had access to internet services the variable assumed the value of 1 , while in circumstances where the household had no access to the internet the dependent variable assumed the value of 0 . The independent variables are explained in the table below.

\subsection{Independent variables}

Table 1: The independent variables used in this study

\begin{tabular}{|c|c|}
\hline $\begin{array}{l}\text { Independent } \\
\text { variable }\end{array}$ & Description of the Variables \\
\hline Race & $\begin{array}{l}\text { This variable assumes the following variables } 1=\text { African Black, } \\
2=\text { Coloured, } 3=\text { Indian/Asian, } 4=\text { White. Apriori expectation is } \\
-/+ \text {, this depends on the reference category. }\end{array}$ \\
\hline Gender & $\begin{array}{l}\text { This variable is a dummy variable where } 1=\text { male and } 0 \\
\text { otherwise. The apriori expectation is }+/- \text { depending on the } \\
\text { reference category. }\end{array}$ \\
\hline Age & $\begin{array}{l}\text { The number of years of an individual. The variable is expected } \\
\text { to have a positive influence on access to the internet. }\end{array}$ \\
\hline $\begin{array}{l}\text { Household } \\
\text { expenditure }\end{array}$ & $\begin{array}{l}\text { This is the total expenditure of the household per month. The } \\
\text { apriori expectation for the variable is }+/- \text {. }\end{array}$ \\
\hline $\begin{array}{l}\text { Net household } \\
\text { income }\end{array}$ & $\begin{array}{l}\text { Net household income is the income received by the } \\
\text { household. The apriori expectation is }+/ \text { - influence on access } \\
\text { to the internet }\end{array}$ \\
\hline Telephone & $\begin{array}{l}\text { This variable is a dummy variable that assumes two variables } \\
o \text { and } 1 \text {. The apriori expectation of the variable is }+/ \text { - depending } \\
\text { on the reference category. }\end{array}$ \\
\hline $\begin{array}{l}\text { Cell } \\
\text { phone/Smartphone }\end{array}$ & $\begin{array}{l}\text { This is a dummy variable that takes two values } 0 \text { and } 1 \text {. It is } \\
\text { expected to have a }+/ \text { - depending on the reference category. }\end{array}$ \\
\hline Access to electricity & $\begin{array}{l}\text { This is a dummy variable that also takes two values } 0 \text { and } 1 \text {. It } \\
\text { is expected to have a }+/- \text { influence depending on the reference } \\
\text { category }\end{array}$ \\
\hline House ownership & $\begin{array}{l}\text { This variable is a dummy variable that takes two values } 0 \\
\text { and } 1 \text { and it is expected to have } a+/ \text { - influence on access to } \\
\text { the internet. }\end{array}$ \\
\hline
\end{tabular}

Source: Authors Analysis 


\subsection{Empirical Model: The Logit Model}

The dependent variable, in this case, is dichotomous which motivated the use of the logistic regression analysis. The equation of the logit model transforms the log-odds of success to a linear component as shown below:

$$
\log \left(\frac{\pi_{i}}{1-\pi_{i}}\right)=\sum_{k=0}^{K} x_{i k} \beta_{k} i=1,2, \ldots, N
$$

In equation one, to find parameters where the probability of the observed data is the greatest, we should use maximum likelihood estimation. To proceed with the estimation of the logit model, the first thing is to state the probability that $Y=1$. The probability $Y=0$ is written as $1-\hat{P}$. Where $\hat{P}$ is the probability? $Y=1$ and $Y=0$ only show whether the household has access to the internet or not. $Y=$ 1 when a household has access to the internet and $Y=0$ is when a household does not have internet access. This will drive lead to the following equation:

$$
\ln \left(\frac{P}{1-P}\right)=\beta_{0}+\beta_{1} X
$$

To find the expected probability that $Y=1$ for all the values of $X$ is calculated as shown in equation 3 :

$$
\hat{P}=\frac{\exp \left(\beta_{0}+\beta_{1} X\right)}{1+\exp \left(\beta_{0}+\beta_{1} X\right)}=\frac{e^{\beta_{0}+\beta_{1} X}}{1+e^{\beta_{0}+\beta_{1} X}}
$$

The model with the variables used as the factors influencing the demand for the internet will be expressed as:

$$
\ln \left(\frac{P}{1-P}\right)=\beta_{0}+\sum_{i}^{n} \emptyset_{i}+\sum_{j}^{n} \emptyset_{j}+\varepsilon
$$

Equation 4 above $\sum_{i}^{n} \emptyset_{i}$ represents all the factors in the model, while all the covariates are shown as $\sum_{j}^{n} \emptyset_{j}$. Substitution the above equation with $Z$ will make the equation appear as follows:

$$
\begin{gathered}
\mathrm{Z}=\beta_{0}+\emptyset_{1} \text { Race }+\emptyset_{2} \text { Age }+\emptyset_{3} \text { Household Expenditure }+ \\
\emptyset_{4} \text { Net household income }+\emptyset_{5} \text { Gender }+\emptyset_{6} \text { Cellphone }+\emptyset_{7} \text { Telephone }+ \\
\emptyset_{8} \text { Acess to electricity }+\emptyset_{9} \text { House Onwership }+\varepsilon
\end{gathered}
$$

\section{Results and Discussion}

\subsection{Descriptive Statistics}

\subsubsection{Sample}

The sample comprised of all the population groups in South Africa, Black African, Coloured, Indian, and White. The distribution of the sample is shown in Table 2. 
Table 2. Study of population distribution

\begin{tabular}{lll}
\hline Race & Count out of 20908 & Percentage \\
Blacks African & 17361 & $80.9 \%$ \\
Coloured & 1659 & $7.1 \%$ \\
Indian & 391 & $2.4 \%$ \\
White & 1497 & $9.5 \%$ \\
\hline
\end{tabular}

Source: Author's calculations GHS data

Table 2 shows that $17361(80.9 \%)$ of that sample were Blacks while the remaining 19.1 per cent was shared among the Whites (9.5\%), Coloureds $(7.1 \%)$ and Indian (2.4\%). Table 2 indicates the gender distribution of the population.

Table 3. Gender distribution of the study

\begin{tabular}{lll}
\hline Study's gender distribution & & \\
\hline Gender & Frequency & Percentage \\
Male Headed Households & 11948 & $58.4 \%$ \\
Female-Headed Households & 8960 & $41.6 \%$ \\
Total & 20908 & 100 \\
\hline
\end{tabular}

Source: Author's Analysis GHS data

The logistic regression results are presented in Table 4 below.

Table 4. Logistic regression results

\begin{tabular}{lllllll}
\hline Variables & B & S.E. & Wald & Df & Sig. & Exp(B) \\
\hline Race & & & 1176.068 & 3 & 0.00 & \\
Colored (1) & -1.05 & 0.095 & 121.604 & 1 & 0.00 & 0.35 \\
Indian (2) & 0.226 & 0.154 & 2.155 & 1 & 0.142 & 1.253 \\
White (3) & 1.636 & 0.101 & 261.38 & 1 & 0.00 & 5.136 \\
Telephone (1) & 1.732 & 0.084 & 427.629 & 1 & 0.00 & 5.65 \\
Cellphone (1) & 3.044 & 0.712 & 18.291 & 1 & 0.00 & 20.997 \\
Access to electricity (1) & 3.701 & 1.002 & 13.648 & 1 & 0.00 & 40.484 \\
House ownership (1) & 0.428 & 0.067 & 40.449 & 1 & 0.00 & 1.535 \\
Gender (1) & 0.595 & 0.07 & 72.166 & 1 & 0.00 & 1.812 \\
Age of household head & -0.017 & 0.002 & 52.707 & 1 & 0.00 & 0.983 \\
Net household income & 0.00 & 0.00 & 2.457 & 1 & 0.117 & 1.00 \\
per month in Rand & & & & & & \\
Household expenditure & 0.024 & 0.004 & 47.728 & 1 & 0.00 & 1.025 \\
Constant & -9.01 & 1.236 & 53.145 & 1 & 0.00 & 0.00 \\
\hline
\end{tabular}

Variables Race, Telephone, Cellphone, Access, House ownership, Gender, Age of household head, Net household income per month in Rand, Household expenditure Omnibus Tests of Model Coefficients Chi-square Step 3380.448, Block 3380.448, Model 3380.448 df 11, Sig..000. Model Summary -2 Log-likelihood, 7970.975a, Cox \& Snell R Square, .151, Nagelkerke R .357.

Source: Author's calculations GHS data 
The results from the logistic regression analysis in the table above indicated that variables race, access to telephone landline, access to a cellular cellphone, access to electricity, owning a house, gender, age of the household head, net household per month, and household expenditure were the significant variables in influencing the demand for internet access by household in South Africa. The variables age and being Coloured were the variables that had a negative influence on the demand for the internet. The results indicate that being Coloured in South Africa reduces the probability of the household having access to the internet. The odds of demand for the internet declines by 0.35 for Coloured people compared to Black Africans. The results also indicated that being Indian in South Africa increases the probability of the household having access to the internet. The variable had a positive influence on access to the internet with an odds ratio of 1.253. This means that the probability of demand for internet services increases by 1.253 for Indians compared to Black Africans.

Amongst the three racial groups in South Africa, White had a higher probability of having access to the internet compared to all the other races. The variable White had a positive influence on the demand for internet with an odds ratio of 5.136. This means that the probability of demand for the internet increases by 5.136 for the White population compared to Black Africa the reference category. These results were supported by scholars such as Ono \& Zavodny (2003), Banerj \& Hodge (2007), Kamalu (2012). These scholars discovered the White population had been exposed to the use of internet services for a long time. As a result, they generally dominate its use compared to other races like Blacks, Indians, and Hispanics. Also, the results indicated that access to the telephone increases the probability of a household having access to internet services. The variable had a positive influence on access to internet services. The odds of demand for internet services by households with telephone access at home was 5.65. This means that the probability of demand for internet increases by 5.65 for households with telephone access compared to households without access to a telephone at home. These results imply that it is easy for households with the telephone at home to subscribe to internet services compared to households without internet access.

Again, the results revealed that access to a cellphone increases the probability of a household having internet access. The result was significant at a 1 per cent level of significance with an odds ratio of 20.997 . The probability of a household increases by 20.997 for households with cellphones compared to households without a cellphone. This variable was significant at a 1 per cent level of significance. The results imply that owning a cellphone in South Africa motivated households to subscribe to internet services compared to circumstances where individuals had no access to a cellphone. These findings were supported by various scholars, for instance, Statistics South Africa (2020) and Siaw et al. (2020) discovered that many internet users in South Africa make use of their telephone and cell phones to have internet access. The World Bank (2020a) also reported that an increase in cell phone and telephone ownership increases internet usage.

The results also indicated that access to electricity had a positive influence on access to internet services. The variable was significant at a 1 per cent level of significance with an odds ratio of 40.484 . Households with access to electricity had more probability of having access to electricity compared to households without electricity. The probability of access to the internet increases by 40.484 compared to 
households without electricity. This means that to increase access to the internet in South Africa, it is imperative to increase access to electricity by households. These findings agreed with the findings of Armey and Laura (2015) and McKeown et al. (2007) who discovered a positive relationship between access to electricity and internet usage. The argument from these studies was that access to electricity increases the chances of a household to access the internet in developed countries which can be the case in developing nations.

Also, the results indicated that households with their property had a higher probability of having access to the internet compared to households without a house. The variable house ownership was significant at 1 per cent with an odds ratio of 1.535. This implies that the probability of access to electricity increases by 1.535 for households with their own houses compared to households without houses. The variable gender was also significant in influencing access to the internet by households in South Africa. The variable was significant at a 1 per cent level of significance with an odds ratio of 1.812. This means that the probability of access to the internet increases by 1.535 for males compared to females. Males had a higher probability of access to internet services compared to females. This might be due to the different chances of access to income by females and males.

Also, the results indicated that the age of the household head had a negative influence on access to the internet by households in South Africa. The variable was significant at a 1 per cent level of significance ( $P$-value, 0.00$)$ and the odds ratio of 0.983 . The variable implies that a unit change in the age of the household head will lead to a decline in the demand for internet by approximately 0.983 . This may be because when a person grows older, their income stream declines which may affect their demand for internet broadband. The variable net household income was also significant at a 10 per cent level of significance in influencing access to broadband with a P-value of 0.117 and an odds ratio of 1.00. The variable net household income had a small coefficient, and this may be the reason why the variable had a small coefficient. On the other hand, the variable net household expenditure was also significant in influencing access to internet services. The variable was significant at a 1 per cent level of significance with a P-value of 0.000 and an odds ratio of 1.025 . The probability of access to internet services increases by approximately 1.025 when the household increases its expenditure. The studies by Chaudhuri et al. (2005) and Hargittai (2003) found age to have an inverse relationship with the use internet, the scholars argued that young age has access to internet use compared to old age because young age has more access to computers and electrical gadgets that use the internet. Billon et al. (2009) further argued that most of the population in developing countries includes young people and the probability of them using the internet is higher compared to old age. Another possible explanation is that young age does not have intense household expenditure compared to old people, therefore, they spend most of their expenses on the internet (Billon et al., 2017; Smith \& Graham, 2012).

\section{Conclusion and Policy Recommendation}

This study aimed to investigate the factors that influence access to the internet by households in South Africa. Access to broadband facilities by individuals, households and consumers is one of the critical components of the economic growth 
and prosperity of a country. It is generally believed that the access to broadband technologies by a community or nation helps to increase productivity which assists a lot in fueling economic growth which will have an impact on the levels of poverty. Using the logistic regression, the study discovered that variables race, access to telephone landline, access to a cellular cellphone, Access to electricity, owning a house, gender, age of the household head, net household per month, and household expenditure were the significant variables in influencing the demand for internet access by household in South Africa. The variables age and being Coloured were the variables that had a negative influence on the demand for the internet. For instance, the results indicate that being Coloured in South Africa reduces the probability of the household having access to the internet. The odds of demand for the internet declines by 0.35 for Coloured people compared to Black Africans. Variables that were outstanding in influencing access to internet services were availability of electricity in the home, access to a cellphone, telephone and being White. The study recommends that in the quest to uplift the lives of the people, the government should try and improve access to electricity.

The current study investigates the factors that influence internet demand by households in Sub-Saharan Africa. Data accessibility and availability influenced the variables used to carry out the investigation which are Race, Age, Household Expenditure, Net household income, Gender, Cellphone, Telephone, Access to electricity, House Ownership. Future research must consider other variables such as the level of education and distance to the nearest service provider among many variables.

\section{References}

Armey, L. \& Hosman, L. (2015). The centrality of electricity to ICT uses in low-income countries. Telecommunications Policy. 10.1016/j.telpol.2015.08.005.

Al-Hammadany, F. H., \& Heshmati, A. (2011). Determinants of Internet Use in Iraq. In International Journal of Communication (Vol. 5). http://ijoc.org.

Ang, S., Lim, E., \& Malhotra, R. (2020). Health-Related Difficulty in Internet Use Among Older Adults: Correlates and Mediation of Its Association with Quality of Life Through Social Support Networks. The Gerontologist. https://doi.org/10.1093/geront/gnaa096

Banerjee, S., \& Hodge, A. (2007). Internet Usage: A Within Race Analysis. Race, Gender \& Class, 14(3/4), 228-246.

BBC-WebWise. (2012). BBC - WebWise - What is the internet? http://www.bbc.co.uk/webwise/guides/what-is-the-internet.

Billon, M., Marco, R., \& Lera-Lopez, F. (2009). Disparities in ICT adoption: A multidimensional approach to study the cross-country digital divide. Telecommunications Policy, 33(10-11), 596-610. https://doi.org/10.1016/j.telpol.2009.08.006

Billon, M., Marco, R., \& Lera-Lopez, F. (2017). Innovation and ICT use by firms and households in the EU: A multivariate analysis of regional disparities. Information Technology and People, 30(2), 424-448.

https://doi.org/10.1108/ITP-05-2015-0098 
Chaudhuri, A., Flamm, K. S., \& Horrigan, J. (2005). An analysis of the determinants of internet access. Telecommunications Policy, 29(9-10), 731-755. https://doi.org/10.1016/j.telpol.2005.07.001

Chung, M., \& Kim, J. (2016). The internet information and technology research directions are based on the fourth industrial revolution. KSII Transactions on Internet and Information Systems, 10(3), 1311-1320. https://doi.org/10.3837/tiis.2016.03.020

Drake, C., Zhang, Y., Chaiyachati, K. H., \& Polsky, D. (2019). The limitations of poor broadband internet access for telemedicine use in rural America: An observational study. In Annals of Internal Medicine (Vol. 171, Issue 5, pp. 382384). American College of Physicians. https://doi.org/10.7326/M19-0283

Flamm, K., \& Chaudhuri, A. (2007). An analysis of the determinants of broadband access. Telecommunications Policy, 31(6-7), 312-326.

https://doi.org/10.1016/j.telpol.2007.05.006

Grosso, M. (2006). Determinants of Broadband Penetration in OECD Nations.

Hargittai, E. (2003). How wide a Web? Inequalities in accessing information online. Unpublished doctoral dissertation, Princeton University, Princeton,

Kamalu, Ngozi C., Internet Use Among Racial/ Ethnic Groups in The United States (2012). Government and History Faculty Working Papers. 15.

https://digitalcommons.uncfsu.edu/govt_hist_wp/15

Kekana, A. G. (2013). The evolution of broadband policy and regulation in South Africa.

Lee, M. H., Yun, J. H. J., Pyka, A., Won, D. K., Kodama, F., Schiuma, G., Park, H. S., Jeon, J., Park, K. B., Jung, K. H., Yan, M. R., Lee, S. Y., \& Zhao, X. (2018). How to respond to the Fourth Industrial Revolution or the second information technology revolution? Dynamic new combinations between technology, market, and society through open innovation. Journal of Open Innovation: Technology, Market, and Complexity, 4(3).

https://doi.org/10.3390/joitmc4030021

Lembani, R., Gunter, A., Breines, M., \& Dalu, M. T. B. (2020). The same course, different access: the digital divide between urban and rural distance education students in South Africa. Journal of Geography in Higher Education, 44(1), 70-84. https://doi.org/10.1080/03098265.2019.1694876

Lera-López, F., Billon, M., \& Gil, M. (2009). Determinants of Internet use in Spain.

Li, G., Hou, Y., \& Wu, A. (2017). Fourth Industrial Revolution: technological drivers, impacts and coping methods. Chinese Geographical Science, 27(4), 626-637. https://doi.org/10.1007/s11769-017-0890-x

McKeown, L., Noce, A.A., \& Czerny, P. (2007). Factors Associated with Internet Use: Does Rurality Matter?

Mhlanga, D. (2020a). Artificial Intelligence (Al) and Poverty Reduction in the Fourth Industrial Revolution (4IR). https://doi.org/10.20944/preprints202009.0362.v1

Mhlanga, D. (2020b). Industry 4.0 in finance: the impact of artificial intelligence (ai) on digital financial inclusion. International Journal of Financial Studies, 8(3), 114. https://doi.org/10.3390/ijfs 8030045

Mhlanga, D., \& Moloi, T. (2020). The stakeholder theory in the fourth industrial revolution. International journal of economics and finance studies, 12(2), 20201309. https://doi.org/10.34109/ijefs.202012207 
Mhlanga, D. (2020). Industry 4.0: The Challenges Associated with The Digital Transformation of Education in South Africa. https://www.researchgate.net/publication/344230555

Nishijima, M., Ivanauskas, T. M., \& Sarti, F. M. (2017). Evolution and determinants of the digital divide in Brazil (2005-2013). Telecommunications Policy, 41(1), 12-24. https://doi.org/10.1016/j.telpol.2016.10.004

Ono, H., Zavodny, M. Race, internet usage, and e-commerce. Rev Black Polit Econ 30, 7-22 (2003). https://doi.org/10.1007/BF02717319.

Park, S. C. (2018). The Fourth Industrial Revolution and implications for innovative cluster policies. Al and Society, 33(3), 433-445.

https://doi.org/10.1007/s00146-017-0777-5

Siaw, Anthony \& Jiang, Yuansheng \& Ankrah Twumasi, Martinson \& Agbenyo, Wonder. (2020). The Impact of Internet Use on Income: The Case of Rural Ghana. Sustainability. 12. 1-16. 10.3390/su12083255.

Schwab, K. (2017). The Fourth Industrial Revolution. https://www.weforum.org/about/the-fourth-industrial-revolution-by-klaus-schwab/

Smith, D.T. \& Graham, R. (2011). Internet as digital practice: Examining differences in African American internet usage. Future Internet, 3(3), 185-203. https://doi.org/10.3390/fi3030185

Seymour, L. F., \& Naidoo, M. (2020). The Usage and Impact of Broadband: A South African Household analysis. www.ejise.com

Statista. (2020). Digital users worldwide 2020 | Statista. https://www.statista.com/statistics/617136/digital-population-worldwide/

Statistics in South Africa. 2020. Population Characteristics. http://www.statssa.gov.za/?cat=15

Stats SA. (2018). General Household Survey-P03182018. www.statssa.gov.za

Stats SA. (2019). General Household Survey-. P0318 www.statssa.gov.za

The World Bank. (2020a). Connecting for Inclusion: Broadband Access for All. https://www.worldbank.org/en/topic/digitaldevelopment/brief/connecting-forinclusion-broadband-access-for-all

The World Bank. (2020b). Individuals using the Internet (\% of the population) | Data. https://data.worldbank.org/indicator/IT.NET.USER.ZS

Trudel, D. (2019). From Internet Access Provision to Digital Rights Activism: The History of the French Data Network.

Xu, M., David, J. M., \& Kim, S. H. (2018). The fourth industrial revolution: Opportunities and challenges. International Journal of Financial Research, 9(2), 90-95. https://doi.org/10.5430/ijfr.v9n2p90 